\title{
The Antecedents of Customer Loyalty: An Empirical Investigation in Life Insurance Context
}

\author{
Alok Kumar Rai, Srivastava Medha
}

\begin{abstract}
The present paper seeks to offer the most decipherable and widely applicable antecedents of customer loyalty. It explores the extant literature on customer loyalty and brings out seven variables which are responsible for formation of customer loyalty. Further, the relative importance of these variables has been ascertained through Multiple Regression Analysis which revealed that service quality and commitment are the strongest predictors of customer loyalty in the Indian life insurance industry. The paper also attempts to assess the loyalty status of life insurance customers in India and draw a comparison between public and private sector life insurance companies in order to provide significant insights to the life insurance companies that may assist them in devising better loyalty practices. The findings suggest that Indian customers do care about the public sector status of a financial service provider as it entails a sense of security and stability and thus creates a difference between customer loyalty of public sector life insurer and that of private sector life insurer. The paper holds significant implications for academicians interested in dynamics of customer loyalty as well as the marketers of life insurance services who are concerned with customer relationships.
\end{abstract}

Key words: customer loyalty, service quality, customer satisfaction, relative importance, life insurance.

\section{INTRODUCTION}

There is an observable worldwide shift toward loyalty marketing in most of the sectors across various industries. The earlier business goal of ensuring customer satisfaction has got undermined due to prevailing colossal relationship orientation of businesses that calls for going beyond the boundaries of satisfaction and create a commitment based enduring association with customers that renders immunity to the business against competitive pressures. Apart from bringing it to the centre stage of customer related affairs of the company, the ethereal, yet corporeal advantages of customer loyalty have rendered it a place of supreme importance in academic circles as well. The value of customer loyalty for service industries has been recognized by many researchers (Bloemer et al., 1999; Caruana, 2002; Asuncion et al., 2004). Keaveney (1995); Gremler and Brown (1996) underlined its potential effect on the development of sustained competitive edge for the service organizations. The distinctive nature of services, increased role of technology and higher customer involvement in service delivery processes have furthered the importance of customer loyalty in service industries. Customer loyalty not only ensures repeat purchases and positive publicity with greater value in terms of reliability, it also leads to host of other significant benefits such as cross buying intentions, exclusive and priority based preference to the company and its products/ services, greater share of wallet and so on which provide a competitive edge to the company. Owing to these discernible and some other latent outcomes of customer loyalty 
like convivial attitude towards company's business policies, integrated marketing communication, new products and customer service initiatives, greater tolerance in the event of service failure and lower resistance to price ups, etc., companies are hugely interested in a systematic and well-assisted development of loyalty behaviours among their customers. Terblanche and Boshoff (2006) agreed that comprehending the precursor of loyalty is a requisite if one wants to attain the maximum benefits of loyalty. Hence, there is a pressing need for deeper exploration into the precursors of loyalty that not only operate as its sources but also act as enhancers.

In the age of cut throat competition and heightened customer expectations, cutting on defection and building bonds of long lasting loyalty with the customers seem to be the only means of sustained profitability and growth. Life insurance services form a prominent portion of Indian customers' investment portfolio and thus, hold great potential and prospects of profits and growth. However, life insurance industry in India is also faced with a number of challenges as on one hand, relaxation in FDI limit is sure to intensify the competitive pressures whereas increased customer awareness and expertise elevate customers' expectations several levels up and reduce the zone of tolerance. Thus, the significance and relevance of customer loyalty and the factors responsible for its formation become all the more palpable in life insurance industry.

\section{THEORETICAL FRAMEWORK}

In context of personal relationships, loyalty implies a feeling or an attitude of devoted attachment caused by affection. Such attachment makes a person feel responsible to persevere with that relationship even in adverse times. However, loyalty in commercial relationships involving company and its' customer denote a subtly different meaning. Rundle - Thiele (2005) explained this change in meaning of loyalty and opined that loyalty in business relationships misses the component of 'an attitude of devoted attachment'. A customer can persevere in his relationship with the company and exhibit loyal behaviours on the basis of his faith in the brand. He defined loyalty as:

"The state or quality of being loyal, where loyalty is defined as a customer's allegiance or adherence towards an object."

- Rundle - Thiele (2005)

The following section is an attempt to elucidate on the concept of customer loyalty and position of loyalty related research in life insurance industry.

\subsection{Customer Loyalty}

Yi (1990); Hallowell (1996); Homburg and Giering (2001) noted that initially, customer loyalty has been perceived to be a behavioural concept entailing repeat buying of product or service measured as the series or share of purchases, referrals, magnitude of relationship or all of the above mingled together. Day (1969) found the behavioural conceptualization of loyalty insufficient for distinguishing true loyalty from fake one and suggested that loyalty should be evaluated through both behavioural and attitudinal measures. Researchers such as Jacoby and Kyner (1973), Dick and Basu (1994), Oliver (1997) and Berne' et al. (2001) highlighted the attitudinal dimension of loyalty. The need of incorporating an attitudinal component of loyalty has been emphasized by Bandyopadhyay and Martell (2007) who revealed that situational factors like 
unavailability of stock, individual factors like resistance to change and socio-cultural factors like social bonding form a cause to differentiate behavioural loyalty from attitudinal loyalty.

Referring to Oliver (1997), Walsh et al. (2008) defined loyalty as a "deeply held commitment to re-buy or re-patronise a preferred product or service consistently in the future, which causes repetitive same-brand or same-brand set purchasing, despite any situational influences and marketing efforts that might cause switching behaviour" (p. 982). Baumann et al. (2011) expressed loyalty as attitude and behaviour. Ladhari et al. (2011) conceptualized loyalty as a customer's continued patronage of a particular bank. Underlining the role of satisfaction,

Based upon the above discussion, it is suggested that "Customer Loyalty is a psychological character formed by sustained satisfaction of the customer coupled with emotional attachment formed with the service provider that leads to a state of willingly and consistently being in the relationship with preference, patronage and premium".

\subsubsection{Customer Loyalty in Life Insurance Industry}

Guillen et al. (2008) noted that the number of empirical studies on customer loyalty in the insurance sector is low. They contended that it is important to monitor customer loyalty and business risk for the life insurance companies due to reasons such as access to information related to the quality of portfolio, effective handling of customer recruitment and retention strategies, evaluation of market's competitiveness in the insurance sector and company's position in that market. Durvasula et al. (2004); Tsoukatos and Rand (2006) described life insurance services are highly intangible. Crosby et al. (1990) pointed that life insurance is primarily sold by insurance agents, who are the only touch point for the customers in most cases. According to Lombardi (2005), keeping the customers is crucial for life insurers as a long-lasting association with the customers results in greater instances of cross-selling and positive recommendation intentions. Zeithaml et al. (1996) pointed that the insurance provider gets to recover the selling cost of an insurance policy only when the policy is renewed for three to four years. Moore and Santomero (1999); Diacon and O'Brien (2002) posited that high retention rates are correlated with better financial performance.

Formation of customer loyalty is a thorough process that involves a series of customers' evaluative judgements and other psychographic variables that stem from these service evaluations. Dick and Basu (1994); Oliver (1999) noted that researchers have been identifying and examining many antecedents of customer loyalty towards stores, companies, and brands over the years. Beerli et al (2002) indicated that factors affecting customer loyalty have been attracting a lot of attention in the recent years from academicians as well as marketers in service industry.

\subsubsection{Antecedents of Customer Loyalty}

Ball et al. (2004) reviewed the literature regarding the antecedents of loyalty, both in terms of the business-to-business and business-to-consumer cases. They mentioned that measuring customer loyalty and its determinants into different markets and countries may bring out significant variance in the explanation of loyalty. Further, they explored the antecedents and categorized them into four groups which are depicted in the Figure 1. 


\begin{tabular}{|c|c|c|c|}
\hline $\begin{array}{l}\text { Characteristics of } \\
\text { the Environment }\end{array}$ & $\begin{array}{l}\text { Characteristics of } \\
\text { the Dyadic Rela- } \\
\text { tionship }\end{array}$ & $\begin{array}{l}\text { Characteristics of } \\
\text { the Consumer }\end{array}$ & $\begin{array}{l}\text { Consumer percep- } \\
\text { tions of the firm } \\
\text { or the relationship } \\
\text { with the marketing } \\
\text { firm }\end{array}$ \\
\hline $\begin{array}{l}\text { - Competitive at- } \\
\text { tractiveness and } \\
\text { perceived switch- } \\
\text { ing costs (Jones } \\
\text { et al., 2000) } \\
\text { - Technological } \\
\text { changes (Par- } \\
\text { asuraman and } \\
\text { Grewal, 2000) } \\
\text { - Legal, economic, } \\
\text { or environmental } \\
\text { changes }\end{array}$ & $\begin{array}{l}\text { - Shared norms } \\
\text { (such as solidar- } \\
\text { ity, mutuality, } \\
\text { flexibility, and } \\
\text { conflict/com- } \\
\text { plaint resolution) } \\
\text { (Gundlach et al., } \\
\text { 1995) } \\
\text { - Equity (Oliver } \\
\text { and Swan 1989) } \\
\text { - Spatial proximity } \\
\text { and relationship } \\
\text { duration (Price et } \\
\text { al., 1995) }\end{array}$ & $\begin{array}{l}\text { - Relationship ten- } \\
\text { dency or prone- } \\
\text { ness (Ganesh et } \\
\text { al., 2000) } \\
\text { - Deal proneness } \\
\text { (Lichtenstein et } \\
\text { al., 1995) } \\
\text { - Involvement in } \\
\text { the category }\end{array}$ & $\begin{array}{l}\text { - Overall product } \\
\text { or service satis- } \\
\text { faction (Oliver } \\
\text { 1997) } \\
\text { - Performance } \\
\text { trust and Be- } \\
\text { nevolence trust } \\
\text { (Ganesan, 1994) } \\
\text { - Depth or value } \\
\text { of communica- } \\
\text { tion (Morgan and } \\
\text { Hunt, 1994) } \\
\text { - Firm or brand } \\
\text { image (Anderson } \\
\text { and Weitz, 1989) } \\
\text { - Relationship } \\
\text { quality (Crosby et } \\
\text { al., 1990) } \\
\text { - Relationship sat- } \\
\text { isfaction (Morgan } \\
\text { and Hunt, 1994) }\end{array}$ \\
\hline
\end{tabular}

Fig. 1 - Classification of Customer Loyalty Antecedents. Source: Ball et al. (2004).

The following sections offer most widely accepted antecedents of customer loyalty by first giving a brief explanation of the concept and subsequently, presenting an account of studies that demonstrated their respective links with customer loyalty:

\subsubsection{Service Quality}

According to Fogli (2006) service quality is "a global judgement or attitude relating to a particular service; the customer's overall impression of the relative inferiority or superiority of the organization and its services. Service quality is a cognitive judgement" (p. 4).

Toran (1993) argued that quality should be an essential element of insurance services. Stafford et al. (1998) pointed that insurance providers are putting increasingly more emphasis on service quality and customer satisfaction. They further noted that service quality in insurance industry is measured through complaint ratio which, as put by Wells and Stafford (1995), is the number of received complaints divided by a measure of insurance business in force. 
Service quality is found to be positively related to readiness to recommend the company (Boulding et al., 1993; Parasuraman et al., 1991), willingness to pay more as well as loyalty (Zeithaml et al., 1996). A positive relation has also been reported between service quality and willingness to pay higher prices and customer loyalty (Baker and Crompton, 2000).

Wong and Sohal (2003) attempted to assess the impact of service quality dimensions on customer loyalty at two levels of retail relationships i.e. interpersonal (person to person) level and store (person to firm) level. Their findings suggested that there is a positive association between service quality and customer loyalty and this association is stronger at company level than at the interpersonal level with tangibles being the most significant predictor of loyalty at store level and empathy at interpersonal level.

\subsubsection{Customer Satisfaction}

Oliver (1980) explained that customer satisfaction arises when customers weigh their perceptions of actual service performance against their expectations and any discrepancy between the two generates disconfirmation which can be of three types:

1. Positive disconfirmation: high satisfaction.

2. Negative disconfirmation: high dissatisfaction.

3. Zero disconfirmation.

Oliver (1997) stated that "satisfaction is the consumer fulfilment response. It is a judgment that a product or service feature, or the product or service itself, provided (or is providing) a pleasurable level of consumption-related fulfilment, including levels of under-or over-fulfilment".

Over the years, several researchers such as Ganesan (1994), Mittal, Ross, and Baldasare (1998), Mittal and Kamakura (2001) and others have exhibited customer satisfaction to be influencing the factors that signify customer loyalty or in other words, the long-term orientation of a relationship. Geyskens, Steenkamp and Kumar (1999) considered customer satisfaction as an essential factor responsible for the long-term association between suppliers and buyers. It has often been enunciated that the affect component of satisfaction could stimulate a satisfied customer to patronize the service provider as well as referring its services to others. The positive effect of customer satisfaction on these dimensions of loyalty has been repeatedly voiced in the literature.

\subsubsection{Trust}

Moorman et al. (1993); Morgan and Hunt (1994) presented trust as a vital element of relationships. Mayer et al. (1995) defined trust as "the willingness of the party to be vulnerable to the actions of another party based on the expectation that the other will perform a particular action important to the trust or, irrespective of the ability to monitor or control that other party" (p. 712). Kumra and Mittal (2004) suggested that trust in honesty denotes faith in partner's openness and truthfulness in business communication.

Lim et al. (1997); Garbarino and Johnson (1999); Chaudhuri and Holbrook (2001) underlined the significance of trust in explaining loyalty. Garbarino and Johnson (1999); Chaudhuri and Holbroook (2001) found credibility trust to be affecting loyalty whereas Singh and Sirdeshmukh (2000); Sirdeshmukh et al. (2002) proposed benevolence as a component of trust which explains loyalty. Ball et al. (2004) contended that in a competitive market, lack of trust obstructs loyalty 
formation. Kassim and Abdullah (2010) studied the link between trust and customer loyalty in two cultural contexts i.e., Malaysia and Qatar and found it to be significant. Nguyen and Leclerc (2011) posited that customers in service industry tend to hold positive behavioural attitude toward the brand they trust. Zeithaml et al. (1996); Castaneda (2011); Kaur et al. (2012); Shainesh (2012) perceived trust as a significant marker of customer loyalty.

\subsubsection{Commitment}

Thibault and Kelley (1959) recognized commitment as construct that belongs to literature of social exchange. The relationship literature also regarded commitment as an important dimension. Dwyer et al. (1987); Moorman et al. (1992); Morgan and Hunt (1994) opined that commitment in a relationship is a psychological state where a client has plans to continue the relationship with his existing supplier. Highlighting the role of commitment in relationships, Parasuraman (1991) stated that "relationships are built on the foundation of mutual commitment" (p. 139). Moorman et al (1992) defined commitment as "an enduring attitude or desire for a particular brand or firm. It is the degree to which customers as members of an organization are emotionally connected to an organization, its brand or product, sustained by continues desire to maintain membership". Jones et al. (2010) investigated the dimensionality of commitment as a construct and concentrated on the differential effects of affective, normative and continuance dimensions on an array of consumer responses signifying loyalty such as repurchase intentions, willingness to pay more, fidelity, advocacy, and altruism. They reviewed marketing literature and noted that affective commitment found place in different contexts like channels, sales, services, etc. as a leading factor for varied focal responses of customers in form of repurchase intentions (Wetzels et al., 1998), switching intentions (Fullerton, 2003), and relative attitude (Pritchard et al., 1999).

\subsubsection{Corporate Image}

Aaker (1996) perceived image as "the net result of all the experiences, impressions, beliefs, feelings and knowledge that people have about a company" (p. 113). Minkiewicz et al. (2011) carried their study in leisure services context and defined it as "stakeholders' beliefs, perceptions, feelings and attitudes towards an organisation” (p. 192). They further agreed with Bosch et al. (2006) and expressed the possibility that these perceptions and feelings take shape through customer response to the strategic intent of the organization.

Shlesinger and Graf von der Shulenburg (1993) stipulated that corporate image and service quality affect customers' choice of insurers as well as accepted level of price. Sirgy and Samli (1989) concluded that image has a direct relationship with store loyalty. Bloemer et al. (1998) carried their study in banking industry and reported an indirect relationship between the above mentioned constructs which is mediated by service quality. Kandampully and Suhartanto (2000) stated that in tourism industry, image is a major determining factor behind customers' decision to repurchase and recommend. Ball et al. (2004) concluded that though, there is a considerable association between image and loyalty, it is indirect in nature as satisfaction and trust mediate the relationship. Chun and Davies (2006) in their study concluded that in retail, positive image positively correlates with customer satisfaction which is a significant predictor of loyalty. 


\subsubsection{Switching Costs}

Jackson (1985) described switching cost as the sum total of economic, physical and psychological costs. Porter (1998) opined that switching cost can be considered as the cost of migrating to another service provider. Chen and Wang (2009) stated that switching costs may range from termination costs imposed by current service provider to costs of joining another service provider. Barroso and Picón (2012) chose Spanish insurance market for studying various dimensions of switching costs and their antecedents as well as outcomes and proposed that switching cost is a higher - order construct which is a composition of six dimensions namely (i) benefits loss costs; (ii) personal relationships loss costs; (iii) economic risk costs; (iv) cost of searching and evaluation; (v) set-up costs; and (vi) monetary loss costs. Each of these six dimensions reflected customer's perception of time, money or efforts involved in switching.

Gronhaug \& Gilly (1991); Fornell (1992); Ping $(1993,1997)$ found switching costs to be positively related to customer loyalty. Bateson and Hoffman (1999) argued that customer satisfaction and switching costs are believed to be the most significant predictors of repurchase intentions or repeat buying behaviour. Hauser, Simester, \& Wernerfelt (1994) found that switching costs lessens customers' degree of sensitivity towards satisfaction levels. Similar effects of switching costs had been observed for trust and perceived service quality by Aydin, Ozer \& Arasil (2005) and Wang (2010) respectively. Oliva, Oliver, \& MacMillan (1992); Jones et al. (2000) stipulated that switching costs influence customer loyalty through its interaction with customer satisfaction. Yanamandram and White (2006) noted that customer's perception of higher cost of switching detains him from wandering off to the competitive offers.

\subsubsection{Communication}

Anderson and Narus (1984) perceived communication as a partaking of significant and welltimed formal as well as informal information between a customer and a supplier. Anderson and Narus (1990) perceived communication as an interactive dialogue between company and its customers during the pre-selling, selling, consuming and post-consuming stages. Morgan and Hunt (1994); Lusch and Brown (1996); Johanson and Mattsson (1997) underscored the significance of communication in developing and retaining a relationship. Mohr et al. (1996); Siguaw et al. (2003) argued that it aids in continuing the relationship in time. Claycomb and Martin (2002) stressed on the importance of regular communication with customers while suggesting that extended durations where customers are not contacted should be avoided as regular interactions reduce the perceived risks associated with purchasing. Ndubisi and Chan (2005) suggested that in context of relationship marketing, communication involves rendering trustworthy information, fulfilling promises and informing in case of delivery related problems. Jaya chandran et al. (2005) proposed that the quality of relationship is likely to be improved if customers find it easy to communicate within the relational information processes. Kaveh (2012) developed a research model to study the role of trust, attitude, communication, image, customer satisfaction and service quality in explaining repurchase intention and concluded that communication has a major impact on trust in Iranian context.

Above discussed antecedents of customer loyalty together lead to customer loyalty formation as depicted in Figure 2. 


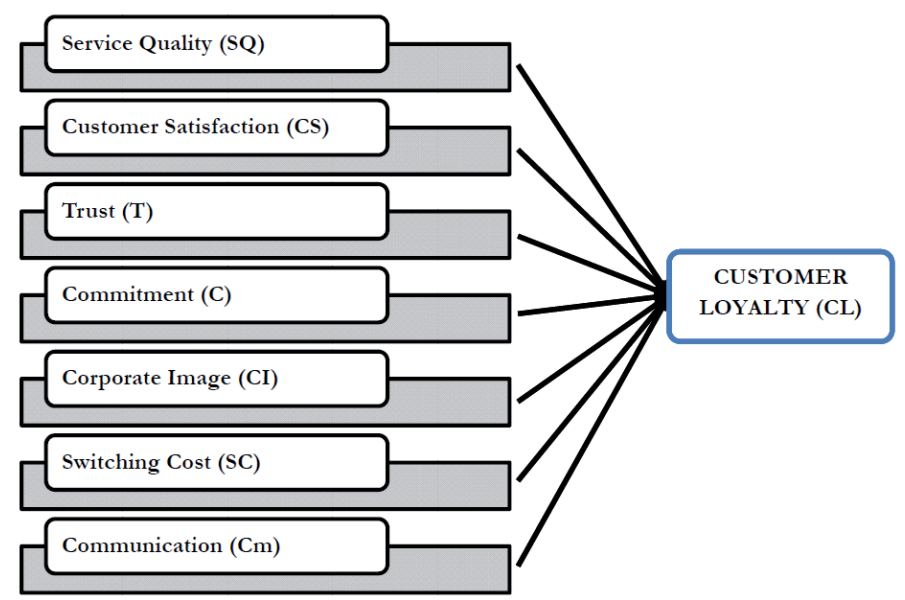

Fig. 2 - Customer Loyalty Formation. Source: own elaboration.

\section{RESEARCH METHOD}

The key research issues of the paper as well as the research techniques employed for addressing these issues are illustrated in the following sections.

\subsection{Research Problem}

Fornell et al (1996); Mittal \& Lassar (1998); Khatibi et al. (2002) argued that extant customer loyalty literature fails to reach at a consensus about determinants of customer loyalty. Knox \& Walker (2001) noted the vagueness in the meaning and measurement of customer loyalty and suggested that more knowledge and comprehension about customer loyalty is required to address the prevailing ambiguity. Several practitioners and academicians in the field of customer loyalty such as Johnson et al. (2006) pointed that the factors principal to loyalty formation are complex and dynamic as they change and evolve over time. Different studies proposed different combinations of variables that are responsible for customer loyalty formation. Clottey et al. (2008) pointed that though various determinants of customer loyalty have been identified but there remains a lack of consensus about the common ones that could be generalized across different industries. This poses a need to bring forth the major antecedents of customer loyalty so that the factors leading to loyalty can be ascertained and used to enforce greater loyalty among customers. Assessing and comparing the loyalty status of customers will also bring greater clarity in terms of identifying the company practices and other situational factors that act as major drivers of customer loyalty in life insurance industry.

Thus, the principal objective of this study is to assess the level of loyalty in life insurance industry and draw a comparison between customer loyalty in public sector and that in private sector. The research objectives guiding the study are as follows:

\subsection{Research Objectives}

1. To identify the factors determining customer loyalty formation.

2. To examine the relative importance of factors which determine formation of customer loyalty. 
Where, $\mathrm{A}$ is a constant. $\mathrm{w}_{1}, \mathrm{w}_{2}, \mathrm{w}_{3} \ldots . \mathrm{w}_{\mathrm{n}}$ represent the relative weights of the factors contributing in formation of customer loyalty as literature suggests that each of the determinants exerts different level of influence over development of loyalty.

3. To establish a predictive model comprised of identified factors responsible for customer loyalty formation.

$$
C L=f\left(F_{1}, F_{2}, F_{3} \ldots F_{n}\right)
$$$$
=A+w_{1}\left(F_{1}\right)+w_{2}\left(F_{2}\right)+w_{3}\left(F_{3}\right)+\ldots . . w_{n}\left(F_{n}\right)
$$

4. To assess customer loyalty of LIC of India vis-a-vis Private Life Insurance Companies.

5. To suggest the initiatives required by life insurance companies in order to develop and maintain loyalty of their customers.

Based upon the theoretical review and research objectives of the study following hypotheses have been framed:

\subsection{Research Hypotheses}

H1: There does not exist any relationship between customer loyalty and factors identified as its antecedents.

$$
\mathrm{R}=0
$$

H2: There is no significant difference between the customer loyalty of public and private life insurance companies.

$$
\mu_{\mathrm{Pub}}=\mu_{\mathrm{Pvt}}
$$

\subsection{Research Design and Procedures}

The research design of present study is twofold as it is exploratory as well as descriptive in nature. The study starts on an exploratory note and research design remains exploratory till the identification of loyalty antecedents. Later, when the assessment of customer loyalty takes centre stage, the research design becomes descriptive.

An instrument for assessment of customer loyalty has been designed on the basis of previously identified antecedents. It consisted of 35 measurement items related to the constructs of service quality, customer satisfaction, trust, commitment, corporate image, switching costs and communication. The study borrowed items from previous researches in the areas of these antecedents where these items have been used to measure their respective construct effectively and modified them as per the context of present study and nature of life insurance services in order to make them more relevant and thus, more effectual. A five - point Likert scale, ranging from " $1=$ strongly disagree" to " $5=$ strongly agree" was used. Table 1 lists the constructs and measures used for assessment of customer loyalty. 
Tab. 1 - Factor wise Items for Assessment of Customer Loyalty. Source: own elaboration.

\begin{tabular}{|c|c|}
\hline Factors & Items \\
\hline \multirow{13}{*}{ Service Quality } & Sufficient range of life insurance products by the company \\
\hline & Reasonable cost of policy \\
\hline & Highly standardized and simple service delivery process \\
\hline & $\begin{array}{l}\text { Technological capability and innovative processes to meet } \\
\text { expectations }\end{array}$ \\
\hline & $\begin{array}{l}\text { Company shows willingness to help and is always ready to } \\
\text { respond to request }\end{array}$ \\
\hline & Convenient branch location \\
\hline & $\begin{array}{l}\text { Positive impression from ambience of company's branch } \\
\text { premises }\end{array}$ \\
\hline & Confidentiality of clients is ensured \\
\hline & Reliable and dependable services \\
\hline & Agents instil confidence \\
\hline & Knowledgeable and competent agents \\
\hline & Empathetic and reassuring approach of agents \\
\hline & Professional appearance of agents \\
\hline \multirow{5}{*}{ Customer Satisfaction } & Company never fails to fulfil expectations \\
\hline & Company has never disappointed so far \\
\hline & $\begin{array}{l}\text { Decision to choose this company for life insurance solutions } \\
\text { was wise }\end{array}$ \\
\hline & $\begin{array}{l}\text { Contented with decision of choosing present life insurance } \\
\text { provider }\end{array}$ \\
\hline & Overall satisfied with life insurance provider \\
\hline \multirow{4}{*}{ Trust } & Company will point out the best alternative \\
\hline & Appropriate advice at critical times from company \\
\hline & Company's honesty \\
\hline & Well-trained agents \\
\hline \multirow{6}{*}{ Commitment } & Company deserves repeat purchasing and recommendations \\
\hline & Strong sense of belongingness to the company \\
\hline & Stay with company because happy to be its customer \\
\hline & Company has a great deal of personal meaning \\
\hline & $\begin{array}{l}\text { Staying with the company because it would be too costly to } \\
\text { leave* }\end{array}$ \\
\hline & $\begin{array}{l}\text { Staying with the company because it provides greater ben- } \\
\text { efits in comparison of other available options }\end{array}$ \\
\hline
\end{tabular}




\begin{tabular}{|l|l|}
\hline \multirow{5}{*}{ Corporate Image } & Company is concerned with the customers \\
\cline { 2 - 2 } & Company can be trusted in what it says and does \\
\cline { 2 - 2 } Switching Costs & Firmly established and stable company \\
\hline & $\begin{array}{l}\text { Unsure about the policy charges of a new life insurance } \\
\text { provider } *\end{array}$ \\
\cline { 2 - 2 } & $\begin{array}{l}\text { Comparing all life insurance providers in order to switch to } \\
\text { a new company is important }\end{array}$ \\
\cline { 2 - 2 } & $\begin{array}{l}\text { Comparing the life insurance providers with one another } \\
\text { takes a lot of energy, efforts and time }\end{array}$ \\
\hline Communication & Timely and trustworthy information from the company \\
\hline
\end{tabular}

The reliability of above research instrument has been examined through Cronbach's Alpha which came out to be .955 and established high reliability value for the instrument. Data has been personally collected within two months duration (November - December 2012) from individual customers of LIC, SBI Life and ICICI Prudential of Varanasi with a life insurance policy of min Rs. 5 lakhs and a policy holding duration of atleast 5 Years. Snowball Sampling has been used to contact the respondents fulfilling these conditions. Out of 515 surveys distributed, 200 pertaining to LIC, 84 of SBI Life and 66 related to ICICI Prudential Life Insurance were found to be complete in all aspects and thus, were considered utilizable for data analysis. A second phase of data collection provided 16 and 34 more surveys pertaining to SBI Life and ICICI Prudential respectively and thus, the total size of sample reached to 400 with 200 for public sector and 100 for each of the private sector life insurance companies. Multiple Regression Analysis and Independent samples t-test in SPSS 16 has been used for testing the hypotheses.

\section{FINDINGS AND DISCUSSION}

A thorough review of literature revealed following seven factors which act as principal antecedents of customer loyalty:

- Service Quality

- Customer Satisfaction

- Trust

- Commitment

- Corporate Image

- Switching Costs

- Communication

Above mentioned factors were further evaluated to ascertain their relative importance in customer loyalty formation. The antecedents of customer loyalty and their relative weight in customer loyalty formation are presented in Figure 3. 


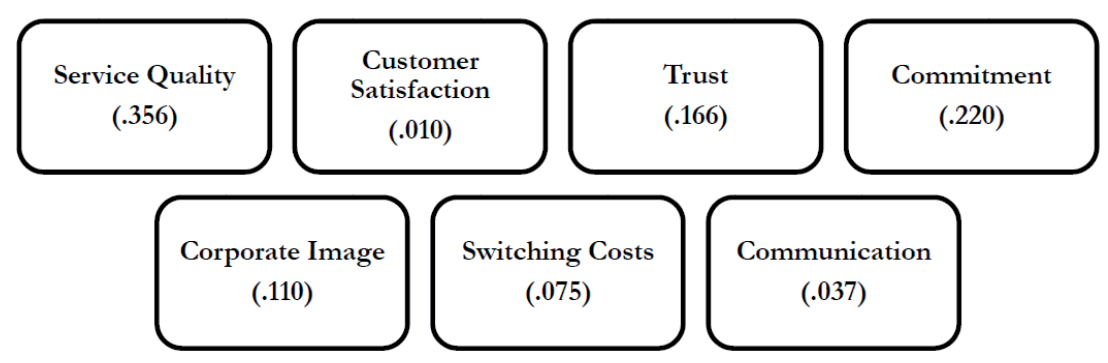

Fig. 3 - Relative Weights of Antecedents. Source: own elaboration.

It is clearly visible that service quality is the most prominent among all factors that play decisive role in customer loyalty formation. Commitment and Trust also emerged as significant factors that affect customer's loyalty. The predictive model for customer loyalty assessment is as follows:

$$
\mathrm{CL}=.174+.356 \mathrm{SQ}+.010 \mathrm{CS}+.166 \mathrm{~T}+.220 \mathrm{C}+.110 \mathrm{CI}+.075 \mathrm{SC}+.037 \mathrm{C}
$$

This also establishes the relationships of customer loyalty with its antecedents and thus, rejects H1.

Assessment of customer loyalty in public and private sector life insurance revealed the dominance of public sector life insurer i.e., LIC in Indian life insurance industry as it stood out with better scores on almost all the items. Following are the depictions of customer loyalty in Indian life insurance industry:

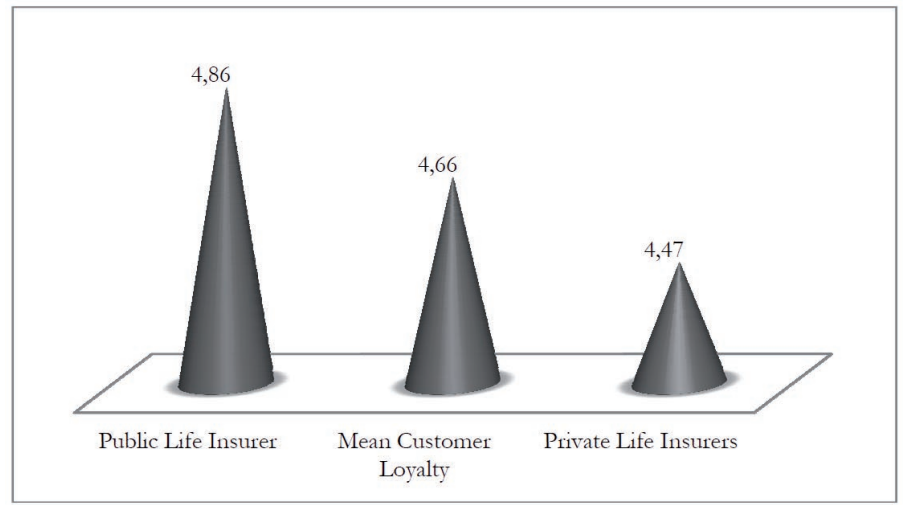

Fig. 4 - Customer Loyalty in Life Insurance. Source: own elaboration.

Mean customer loyalty at LIC, which is the only public sector life insurer in India, is 4.86 whereas it is 4.47 for public sector life insurers. Based upon the responses generated from the customers of LIC, it can be suggested that $69 \%$ of its customers are loyal towards LIC. The responses from select private life insurers suggest the level of customer loyalty in private sector life insurance to be $64 \%$ which is not considerably lesser than public sector.

As far as the individual life insurance providers are concerned, LIC is enjoying highest level of customer loyalty with other two following a close trail. 


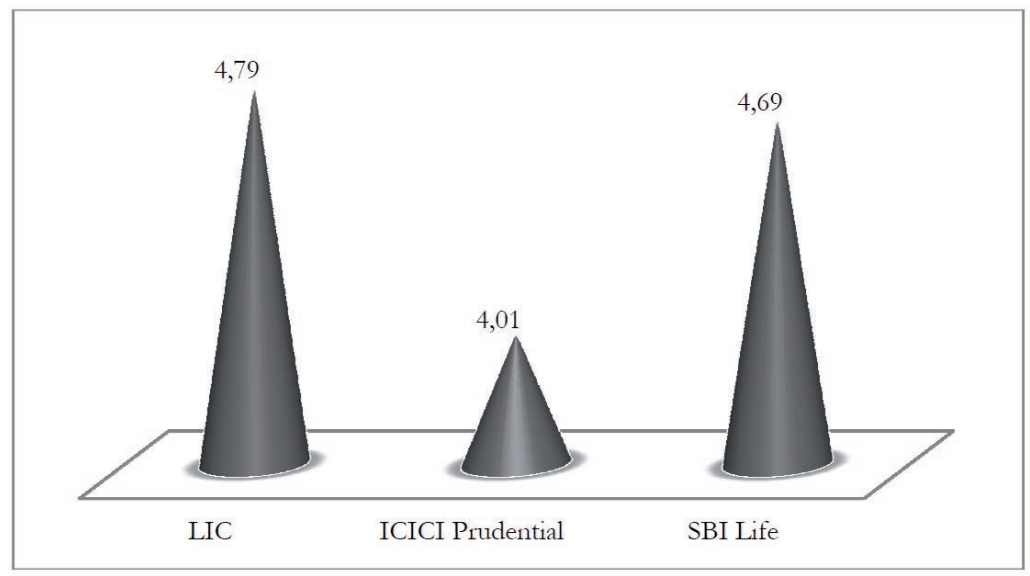

Fig. 5 - Customer Loyalty in Life Insurance (Company Wise). Source: own elaboration.

LIC has secured $68 \%$ customer loyalty which suggests that $68 \%$ of its customers can be considered loyal towards it. SBI Life is not far behind with mean responses of 4.69 which reflect that $67 \%$ of its customers fall into the category of loyal customers. ICICI Prudential has scored 4.01 mean responses i.e., $57 \%$ level of customer loyalty.

To compare the means from two different groups of data, T-test is used since it can help in finding out if means are significantly different from one another or if they are relatively the same. With the help of two sample t-test, the equality between customer loyalty in public sector i.e., LIC and in private sector has been tested. The results are presented in the appendix.

The significance value of F (14.570) under Levene's Test is .000 which is lesser than the default value of .05 . A value less than .05 means that the variability in two conditions is not the same. Practically, it indicates that in order to determine whether there is a significant difference between means of public sector customer loyalty and private sector customer loyalty, we need to refer to Sig (2-Tailed) value in the second row which is .000 .

The Sig (2-Tailed) value is lower than the default value which suggests that $\mathrm{H} 2$ cannot be accepted:

$$
\mu \mathrm{P} \neq \mu \mathrm{Pvt}
$$

Thus, it can be concluded that Customer Loyalty at LIC is significantly different from the that at private life insurance sector. The apparent inconsistency between the numerical mean values of public and private life insurance sector can be attributed to chance errors.

\section{CONCLUSION}

The factors leading to customer loyalty are mainly those which either stem from customers' evaluations and subsequent perceptions of the service such as service quality and customer satisfaction or the ones that fall into the category of relational outcomes of repeated service transactions like trust and commitment. There are few others which are broadly related to the company's own position such as corporate image and communication or industry dynamics like switching 
costs. Thus, this study corroborates to Kahill's (2007) classification of loyalty antecedents and proposes following categorization of antecedents of customer loyalty:
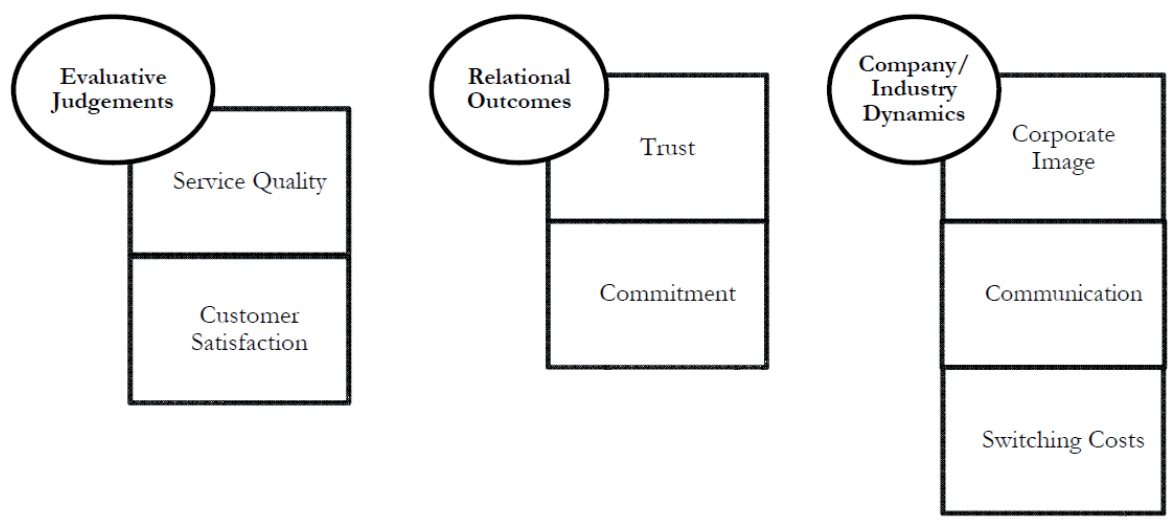

Fig. 6 - Antecedents of Customer Loyalty: A Classification. Source: own elaboration.

In context of life insurance services in India, service quality holds greatest significance for the customers while taking conscious or unconscious decision of binding their loyalty with a life insurer. Customers' level of Commitment and their Trust in life insurer also determine status of their loyalty significantly. An interesting observation is the low strength of customer satisfaction as a predictor of customer loyalty which is peculiar since customer satisfaction has been regarded as an obvious step toward customer loyalty in most of the industries. The low importance of customer satisfaction in predictive model of customer loyalty formation simply corroborates with the higher significance of factors such as trust and commitment which make the customers stay with their life insurer even if their level of satisfaction is poor. This is not unusual in case of financial services as a large number of customers feel apprehensive about the security aspect as well as returns prospect of their investments and prefer to stay with a financially stable company that can assure them about safety of their investment along with sound returns even if the company sometimes fail to conform to their expectation.

Customer loyalty of public and private sector life insurance seem to be same but the real picture is somewhat different. Though, the mean scores of customer loyalty in public and private sectors lie close to each other, the loyalty status of life insurance customers in public sector is found to be significantly different from private sector customer loyalty which suggests that sector does influence customers' decision to stay with the company. Indian customers, while making their decisions regarding financial investment, seem to be keenly considering company's stability and security aspects that are imbibed in the business dynamics of public sector which make them choose LIC over other private life insurance companies. 


\section{IMPLICATIONS}

It should be noted that customer loyalty cannot be created in a vacuum as there are seven other factors which need to be taken care of in order to attain customers' loyalty. Service quality is of primary importance in respect of customer loyalty and life insurers, who desire unwavering loyalty of their customers, should carefully assess and deliver quality services to their customers by offering better products with greater flexibility and reasonable charges, hassle free claim procedures and a proactive and systematic grievance handling mechanism. Such measures will help the companies in instigating committed behaviours among their customers which are another requisite of customer loyalty. To develop trustworthiness of the company, greater transparency and better customer service should be provided to the customers repeatedly. Since life insurance is a latent product with relatively small number of service encounters and almost negligible contact between customers and the life insurer as life insurance business is carried out primarily through agency relationships, a large onus of ensuring loyalty of customer lies on agents. Thus, life insurance companies need to conduct systematic training programs for their agents whereby agents are trained and designed as company's own live loyalty program. Another important aspect of life insurance business is that customers get to evaluate company's service after a considerably long period and thus, it gets difficult to forge customer loyalty since service quality evaluations and resultant commitment take time to materialize. To compensate this, life insurance companies should design active and regular integrated marketing communications addressing general queries and other apprehensions of customers and informing them about new products as well as upgradation in an existing one.

\section{SCOPE FOR FUTURE STUDY}

Present study is focused on evaluating customer loyalty in life insurance industry on the basis of assumed linear relationship of loyalty with its antecedents. Further investigation may be undertaken to explore and establish the possible non-linear relationship between loyalty and its individual antecedents. The antecedents discussed in the literature review section are mainly customer variables which may be classified into evaluative judgements and relational outcomes. Future studies may test the interrelationships of these variables in relation to customer loyalty formation and examine the possible indirect and interactive effects on the relationships of customer loyalty. Researchers may also work in the direction of developing and validating a scale for customer loyalty assessment on the basis of preliminary research instrument used in this study.

\section{LIMITATIONS}

The perceived limitations of this study are primarily concerned with the geographical constraints. The study has been conducted in Uttar Pradesh, a major state of India which limits its genralizability to other countries as cultural and geographical differences create significant distinctions in the pre-consumption expectations and post-consumption evaluations of the customers. Also, the study is focused on the loyalty status of life insurance customers which has resulted in partial coverage of the insurance industry as customer loyalty in general insurance has not been covered at all. 
Assessment of customer loyalty in this study is based upon the antecedents identified from the extant literature and authors' discretion. However, the list of antecedents proposed in this study does not claim to be comprehensive which means that chances of other culture and industry specific loyalty predictors' existence which have not been discussed here are good.

\section{References:}

1. Aaker, D.A. (1996). Building Strong Brands. New York: Free Press.

2. Anderson, J.C., \& Narus, J.A. (1984). A model of the distributor's perspective of distributor-manufacturer working relationships. Journal of Marketing, 48(4), 62-74. http:// dx.doi.org/10.2307/1251511

3. Anderson, J.C., \& Narus, J.A. (1990). A model of distributor firm and manufacturer firm working relationships. Journal of Marketing, 54(1), 42-58. http://dx.doi.org/10.2307/1252172

4. Asuncion, B., Martin, D.J., \& Quintana, A. (2004). Model of customer loyalty in the retail banking market. European Journal of Marketing, 38(1), 253-275.

5. Aydin, S., Özer, G., \& Arasil, O. (2005). Customer loyalty and the effect of switching costs as a moderator variable: A case in the Turkish mobile phone market. Marketing Intelligence \& Planning, 23(1), 89-103. http://dx.doi.org/10.1108/02634500510577492

6. Baker, D. A., \& Crompton, J.L. (2000). Quality, satisfaction and behavioural variables. Annals of Tourism Research, 27(3), 785-804. http://dx.doi.org/10.1016/S0160-7383(99)00108-5

7. Ball, D., Coelho, P.S., \& Machas, A. (2004). The role of communication and trust in explaining customer loyalty: an extension to the ECSI model. European Journal of Marketing, 38(9/10), 1272-1293. http://dx.doi.org/10.1108/03090560410548979

8. Bandyopadhyay, S., \& Martell, M. (2007). Does attitudinal loyalty influence behavioural loyalty? A theoretical and empirical study. Journal of Retailing and Consumer Services, 14(1), 3544. http://dx.doi.org/10.1016/j.jretconser.2006.03.002

9. Barroso, C., \& Picón, A (2012). Multi-dimensional analysis of perceived switching costs. Industrial Marketing Management, 41(3), 531-543. http://dx.doi.org/10.1016/ j.indmarman.2011.06.020

10. Bateson, J.E.G., \& Hoffman, D.K. (1999). Managing services marketing: Text and readings. New York: The Dryden Press.

11. Baumann, C., Elliott, G., \& Hamin, H. (2011). Modelling customer loyalty in financial services: A hybrid of formative and reflective constructs. International Journal of Bank. Marketing, 29(3), 247-267. http://dx.doi.org/10.1108/02652321111117511

12. Beerli, A., Martin, D.J., \& Quintana, A. (2002). A model of customer loyalty in the retail banking market. European Journal of Marketing, 38(1), 253-275. http://dx.doi.org/10.1108/030 90560410511221

13. Berne', C., Mugica, J. M., \& Yague, M. J. (2001). The effect of variety-seeking on customer retention in services. Journal of Retailing and Consumer Services, 8(6), 335-345. http://dx.doi. org/10.1016/S0969-6989(01)00002-9

14. Bloemer, J, Ruyter, K., \& Peeters, P (1998). Investigating drivers of bank loyalty: the complex relationship between image, service quality and satisfaction. International Journal of Bank. Marketing, 16(7), 276-286. http://dx.doi.org/10.1108/02652329810245984 
15. Bloemer, J., Ruyter, K., \& Wetzels, M. (1999). Linking perceived service quality and service loyalty: a multi-dimensional perspective. European Journal of Marketing, 33 (11/12), 1082-1106. http://dx.doi.org/10.1108/03090569910292285

16. Bosch, J., Venter, E., Han, Y., \& Boshoff, C. (2006). The impact of brand identity on the perceived brand image of a merged higher education institution: part two. Management Dynamics, 15(3), 36-54.

17. Boulding, W., Kalra, A., Staelin, R., \& Zeithaml, V. (1993). A dynamic process model of service quality: from expectations to behavioural intentions. Journal of Marketing Research, 30 (1), 7-27. http://dx.doi.org/10.2307/3172510

18. Caruana, A. (2002). Service loyalty. The effects of service quality and the mediating role of customer satisfaction. European Journal of Marketing, 36(7/8), 811-828. http://dx.doi. org/10.1108/03090560210430818

19. Castaneda, J.S. (2011). Relationship between customer satisfaction and loyalty on the internet. Journal of Business Psychology, 26(3), 371-383. http://dx.doi.org/10.1007/s10869-0109196-z

20. Chaudhuri, A., \& Holbrook, M.B. (2001). The Chain of Effects from Brand Trust and Brand Affect to Brand Performance: The Role of Brand Loyalty. Journal of Marketing, 65(2), 81-93. http://dx.doi.org/10.1509/jmkg.65.2.81.18255

21. Chen, M., \& Wang, L. (2009). The moderating role of switching barriers on customer loyalty in the life insurance industry. The Service Industries Journal, 29(8), 1105-1123. http:// dx.doi.org/10.1080/02642060902764574

22. Chun, R., \& Davies, G. (2006). The influence of corporate character on customers \& employees: exploring similarities and differences. Journal of the Academy of Marketing Science, 34(2), 138-146. http://dx.doi.org/10.1177/0092070305284975

23. Claycomb, C., \& Martin, C.L. (2002). Building customer relationships: An inventory of service providers' objectives and practices. Journal of Services Marketing, 16(7), 615-636. http://dx.doi.org/10.1108/08876040210447342

24. Clottey, T. A., Collier, D. A., \& Stodnick, M. (2008). Drivers Of Customer Loyalty In A Retail Store Environment. Journal of Service Science, 1(1), 35-48.

25. Crosby, L.A., Evans, K.R., \& Cowles, D. (1990). Relationship quality in services selling: an interpersonal influence perspective. Journal of Marketing, 54(3), 68-81. http://dx.doi. org $/ 10.2307 / 1251817$

26. Day, G.S. (1969). A Two-Dimensional Concept of Brand Loyalty. Journal of Advertising Research, 9(3), 29-35.

27. Diacon, S., \& O'Brien, C. (2002). Persistency in UK long-term insurance: customer satisfaction and service quality. CRIS Discussion Papers, III. Nottingham: University of Nottingham.

28. Dick, A. S., \& Basu, K. (1994). Customer Loyalty: Toward an Integrated Conceptual Framework. Journal of the Academy of Marketing Science, 22(2), 99-113. http://dx.doi.org/10.1177 /0092070394222001

29. Dong-Mo, K. (2003). Inter-relationships among store images, store satisfaction, and store loyalty among Korea discount retail patrons. Asia Pacific Journal of Marketing and Logistics, 15(4), 42-71. http://dx.doi.org/10.1108/13555850310765033 
30. Durvasula, S., Lysonski, S., Mehta, S.C., \& Tang, B.P. (2004). Forging relationships with services: the antecedents that have an impact on behavioural outcomes in the life insurance industry. Journal of Financial Services Marketing, 8(4), 314-326. http://dx.doi.org/10.1057/ palgrave.fsm.4770129

31. Fogli, L. (2006). Customer Service Delivery. San Francisco: Jossey-Bass.

32. Fornell, C. (1992). A national customer satisfaction barometer: the Swedish experience. Journal of Marketing, 56(1), 6-21. http://dx.doi.org/10.2307/1252129

33. Fornell, C., Johnson, M.D., Anderson, E.W., Cha, J., \& Bryant, B.E. (1996). The American customer satisfaction, index: nature, purpose and findings. Journal of Marketing, 60(4), 7-18. http://dx.doi.org/10.2307/1251898

34. Ganesan, S. (1994). Determinants of long-term orientation in buyer-seller relationships. Journal of Marketing, 58(2), 1-19. http://dx.doi.org/10.2307/1252265

35. Garbarino, E., \& Johnson, M. S. (1999). The Different Roles of Satisfaction, Trust, and Commitment in Customer Relationships. Journal of Marketing, 63(2), 70-87. http://dx.doi. org/10.2307/1251946

36. Geyskens, I., Steenkamp, J.B.E.M., \& Kumar, N. (1998). Generalizations about trust in marketing channel relationships using meta-analysis. International Journal of Research in Marketing, 15(3), 223-248. http://dx.doi.org/10.1016/S0167-8116(98)00002-0

37. Gremler, D.D., \& Brown, S.W. (1996). Service loyalty: its nature, importance, and implications. In Edvardsson, B., Brown, S.W., Johnston, R. \& Scheuing, E. (Eds), QUIS V: Advancing Service Quality: A Global Perspective (171-180). New York: International Service Quality Association.

38. Gronhaug, K., \& Gilly, M.C. (1991). A transaction cost approach to customer dissatisfaction and complaint actions. Journal of Economic Psychology, 12(1), 165-183. http:// dx.doi.org/10.1016/0167-4870(91)90048-X

39. Guillen, M, Neilsen, J. P., \& Perez-Marin, A. M. (2008). The Need to Monitor Customer Loyalty and Business Risk in the European Insurance Industry. The Geneva Papers on Risk and Insurance, 33(1), 207-218. http://dx.doi.org/10.1057/gpp.2008.1

40. Hallowell, R. (1996). The relationship of customer satisfaction, customer loyalty and profitability: an empirical study. International Journal of Service Industry Management, 7(4), 27-42. http://dx.doi.org/10.1108/09564239610129931

41. Hauser, J. R., Simester, D. I., \& Wernerfelt, B. (1994). Customer satisfaction incentives. Marketing Science, 13(4), 327-350. http://dx.doi.org/10.1287/mksc.13.4.327

42. Homburg, Ch., \& Giering, A. (2001). Personal Characteristics as Moderators of the Relationship Between Customer Satisfaction and Loyalty - An Empirical Analysis. Psychology \& Marketing, 18(1), 43-66. http://dx.doi.org/10.1002/1520-6793(200101)18:1<43:: AID-MAR3>3.0.CO;2-I

43. Jackson, B.B. (1985). Winning and Keeping Industrial Customers. Lexington: Lexington Books.

44. Jacoby, J., \& Kyner, D.B. (1973). Brand Loyalty Versus Repeat Purchasing Behavior. Journal of Marketing Research, 10(1), 1-9. http://dx.doi.org/10.2307/3149402

45. Jayachandran, S., Sharma, S., Kaufman, P., \& Raman, P. (2005). The role of relational information processes and technology use in customer relationship management. Journal of Marketing, 69(4), 177-192. http://dx.doi.org/10.1509/jmkg.2005.69.4.177 
46. Johanson, J., \& Mattsson, L.G. (1997). Internationalizations in industrial systems: A network approach. In Ford, D. (Ed.). Understanding Business Markets (194-213). London: Dryden Press.

47. Johnson, M. D, Herrmann, A., \& Huber, F. (2006). The Evolution of Loyalty Intentions. Journal of Marketing, 70(2), 122-132. http://dx.doi.org/10.1509/jmkg.70.2.122

48. Jones, M.A., Beatty, S.E., \& Mothersbaugh, D.V. (2000). Switching barriers and repurchase intentions in services. Journal of Retailing, 76(2), 259-274. http://dx.doi.org/10.1016/S00224359(00)00024-5

49. Jones, T., Fox, G.L., Taylor, S.F., \& Fabrigar, L.R. (2010). Service customer commitment and response. Journal of Services Marketing, 24(1), 16-28. http://dx.doi.org/10.1108/088760410 11017862

50. Kandampully, J., \& Suhartanto, D. (2000). Customer loyalty in the hotel industry: the role of customer satisfaction and image. International Journal of Contemporary Hospitality Management, 12(6), 346-351. http://dx.doi.org/10.1108/09596110010342559

51. Kassim, N., \& Abdullah, N. A. (2010). The effect of perceived service quality dimensions on customer satisfaction, trust, and loyalty in e-commerce settings: A cross cultural analysis. Asia Pacific Journal of Marketing and Logistics, 22(3), 351-371. http://dx.doi.org/10.110 $8 / 13555851011062269$

52. Keaveney, S.M. (1995). Customer switching behavior in service industries: an exploratory study. Journal of Marketing, 59(2), 71-82. http://dx.doi.org/10.2307/1252074

53. Knox, S., \& Walker, D. (2001). Measuring and Managing Brand Loyalty. Journal of Strategic Marketing, 9(2), 111-128. http://dx.doi.org/10.1080/713775733

54. Kumra, R., \& Mittal, R. K. (2004). Trust and its Determinants in Internet Banking: A Study of Private Sector Banks in India. Decision, 31(1), 73-96.

55. Ladhari, R., Ladhari, I., \& Morales, M. (2011). Bank service quality: comparing Canadian and Tunisian customer perceptions. International Journal of Bank Marketing, 29(3), 224-246. http://dx.doi.org/10.1108/02652321111117502

56. Lim, K., \& Razzaque, A.M. (1997). Brand loyalty and situational effects: An interactionist perspective. Journal of International Consumer Marketing, 9(4), 95-115. http://dx.doi. org/10.1300/J046v09n04_06

57. Lombardi, L.J. (2005). The importance of client retention. LIMRA's MarketFacts Quarterly, 24(2), 31-2.

58. Lusch, R.F., \& Brown, J.R. (1996). Interdependency, contracting, and relational behavior in marketing channel. Journal of Marketing, 60(4), 19-38. http://dx.doi.org/10.2307/1251899

59. Mayer, R.C., Davis, J.H., \& Schoorman, F.D. (1995). An integrative model of organizational trust. Academy of Management Review, 20(3), 709-734. http://dx.doi.org/10.5465/

AMR.1995.9508080335

60. Minkiewicz, J., Evans, J., Bridson, K., \& Mavondo, F. (2011). Corporate image in the leisure services sector. Journal of Services Marketing, 25(3), 190-201. http://dx.doi.org/10.1108/08876 041111129173

61. Mittal, B., \& Walfried, M.L. (1998). Why Do customers Switch? The Dynamics of Satisfaction versus Loyalty. Journal of Services Marketing, 12(3), 177-194. http://dx.doi. org/10.1108/08876049810219502 
62. Mittal, V., \& Kamakura, W (2001). Satisfaction, Repurchase Intent, and Repurchase Behavior: Investigating the Moderating Effects of Customer Characteristics. Journal of Marketing Research, 38(1), 131-142. http://dx.doi.org/10.1509/jmkr.38.1.131.18832

63. Mittal, V., Ross, W.T., \& Baldasare, P.M. (1998). The Asymmetric Impact of Negative and Positive Attribute-Level Performance on Overall Satisfaction and Repurchase Intentions. Journal of Marketing, 62(1), 33-47. http://dx.doi.org/10.2307/1251801

64. Mohr, J.J., \& Sohi, R.S. (1995). Communication flows in distribution channels: Impact on assessments of communication quality and satisfaction. Journal of Retailing, 71(4), 393-416. http://dx.doi.org/10.1016/0022-4359(95)90020-9

65. Moore, J.F., \& Santomero, A.M. (1999). The industry speaks: results of the WFIC insurance survey. In Cummins, J.D., \& Santomero, A.M. (Eds.), Changes in the Life Insurance Industry: Efficiency, Technology and Risk Management (19-74). Norwell, MA: Kluwer. http://dx.doi. org/10.1007/978-1-4615-5045-7_2

66. Moorman, C., Zaltman, G., \& Deshpande, R. (1992). Relationship between providers and users of market research: the dynamic of trust within and between organisations. Journal of Marketing Research, 29(3), 314-328. http://dx.doi.org/10.2307/3172742

67. Moorman, C., Zaltman, G., \& Deshpande, R. (1993). Factors affecting trust in marketing relationships. Journal of Marketing, 57(1), 81-101. http://dx.doi.org/10.2307/1252059

68. Morgan, R., \& Hunt, S. (1994). The commitment-trust theory of relationship marketing. Journal of Marketing, 58(3), 20-38. http://dx.doi.org/10.2307/1252308

69. Ndubisi, N.O., \& Chan, K.W. (2005). Factorial and discriminant analyses of the underpinnings of relationship marketing and customer satisfaction. International Journal of Bank Marketing, 23(3), 542-557. http://dx.doi.org/10.1108/02652320510629908

70. Nguyen, N., \& Leclerc, A. (2011). The effect of service employees' competence on financial institutions' image: benevolence as a moderator variable. Journal of Services Marketing, 25(5), 349-360. http://dx.doi.org/10.1108/08876041111149702

71. Oliva, T. A., Oliver, R. L., \& MacMillan, I.C. (1992). A catastrophe model for developing service satisfaction strategies. Journal of Marketing. 56(3), 83-95. http://dx.doi. org/10.2307/1252298

72. Oliver, R. (1980). A Cognitive Model of the Antecedents and Consequences of Satisfaction Decisions. Journal of Marketing Research, 17(4), 460-469. http://dx.doi.org/10.2307/3150499

73. Oliver, R. L. (1997). Satisfaction: A Behavioral Perspective on the Consumer. New York: McGrawHill.

74. Oliver, R. L. (1999). Whence customer loyalty? Journal of Marketing, 63, 33-44. http://dx.doi. org/10.2307/1252099

75. Parasuraman, A., Berry L.L., \& Zeithaml, V.A. (1991). Refinement and Reassessment of the SERVQUAL Scale. Journal of Retailing, 67(4), 420-450.

76. Ping, R.A. (1993), The effects of satisfaction and structural constraints on retailer exiting, voice, loyalty, opportunism, and neglect. Journal of Retailing, 69(3), 320-353. http://dx.doi. org/10.1016/0022-4359(93)90010-G

77. Ping, R.A. (1997). Voice in business to business relationships: Cost of exit and demographic antecedents. Journal of Retailing, 73(2), 261-281. http://dx.doi.org/10.1016/S00224359(97)90006-3 
78. Porter, M. (1998). Competitive Strategy: Techniques for Analyzing Industries and Competitors. New York: The Free Press.

79. Shainesh, G. (2012). Effects of trustworthiness and trust on loyalty intentions: validating a parsimonious model in banking. International Journal of Bank Marketing, 30(4), 267-279. http:// dx.doi.org/10.1108/02652321211236905

80. Schlesinger, H., \& Graf von der Shulenburg, J.M. (1993). Consumer information and decisions to switch insurers. Journal of Risk \& Insurance, 60(4), 591-615. http://dx.doi. org $/ 10.2307 / 253381$

81. Rundle-Thiele, S. (2005). Loyalty: An empirical exploration of theoretical structure in two service markets. Unpublished Doctoral Dissertation., Adelaide, Australia: University of South Australia.

82. Siguaw, J.A., Baker, T., \& Simpson, P.M. (2003). Preliminary evidence on the composition of relational exchange and its outcomes: The distributor perspective. Journal of Business Research, 56(4), 311-322. http://dx.doi.org/10.1016/S0148-2963(02)00443-5

83. Singh, J., \& Sirdeshmukh, D. (2000). Agency and trust mechanisms in customer satisfaction and loyalty judgements. Journal of the Academy of Marketing Science, 28 (1), 150-167. http:// dx.doi.org/10.1177/0092070300281014

84. Sirdeshmukh, D., Singh, J., \& Sabol, B. (2002). Consumer trust, value and loyalty in relational exchanges. Journal of Marketing, 66(1), 15-37. http://dx.doi.org/10.1509/ jmkg.66.1.15.18449

85. Sirgy, M.J., \& Samli, A.C. (1989). A path analytic model of store loyalty involving selfconcept, store image, geographic loyalty, and socioeconomic status. Journal of the Academy of Marketing Science, 13(3), 265-291. http://dx.doi.org/10.1007/BF02729950

86. Stafford, M.R., Stafford, T.F., \& Wells, B.P. (1998). Determinants of service quality and satisfaction in the auto casualty claims process. Journal of Services Marketing, 12(6), 426-440. http://dx.doi.org/10.1108/08876049810242687

87. Terblanche, N.S., \& Boshoff, C. (2006). A generic instrument to measure customer satisfaction with the controllable elements of the in-store shopping experience. South African Journal of Business Management, 37(3), 1-14.

88. Thibault, J.W., \& Kelley, H.H. (1959). The Social Psychology of Groups. New York, NY: John Wiley and Sons.

89. Toran, D. (1993). Quality service (quality everything!). LIMR A'S Market Facts, 12(2), 10-11.

90. Tsoukatos, E., \& Rand, G. K. (2006). Path analysis of perceived service quality, satisfaction and loyalty in Greek insurance. Managing Service Quality, 16(5), 501-519. http://dx.doi. org/10.1108/09604520610686746

91. Walsh, G., Evanschitzky, H., \& Wunderlich, M. (2008). Identification and analysis of moderator variables: Investigating the customer satisfaction-loyalty link. European Journal of Marketing, 42(9), 977-1004. http://dx.doi.org/10.1108/03090560810891109

92. Wang, C. (2010). Service quality, perceived value, corporate image, and customer loyalty in the context of varying levels of switching costs. Psychology \& Marketing, 27(3), 252-262. http://dx.doi.org/10.1002/mar.20330

93. Wells, B.P., \& Stafford, M.R. (1995). Service quality in the insurance industry: Consumer perceptions versus regulatory perceptions. Journal of Insurance Regulation, 13(4), 462-477. 
94. Yanamandram, V., \& White, L. (2006). Switching barriers in business-to-business services: a qualitative study. International Journal of Service Industry Management, 17(2), 158-192. http:// dx.doi.org/10.1108/09564230610656980

95. Yi, Y., \& La, S. (2004). What influences the relationship between customer satisfaction and repurchase intention? Investigating the effects of adjusted expectations and customer loyalty. Psychology and Marketing, 21(5), 351-373. http://dx.doi.org/10.1002/mar.20009

96. Zeithaml, V.A., Berry, L.L., \& Parasuraman, A. (1996). The behavioural consequences of service quality. Journal of Marketing, 60(2), 31-46. http://dx.doi.org/10.2307/1251929

\section{Contact information}

Alok Kumar Rai

Professor

Medha Srivastava

Research Scholar

Faculty of Management Studies

Banaras Hindu University

Email:alok.fmsbhu@gmail.com; srivastava.medha@gmail.com 
APPENDICES:

\begin{tabular}{|c|c|c|c|c|c|}
\hline \multicolumn{2}{|c|}{ Group Statistics } \\
\hline & Sector & $\mathrm{N}$ & Mean & $\begin{array}{c}\text { Std. Devia- } \\
\text { tion }\end{array}$ & $\begin{array}{c}\text { Std. Error } \\
\text { Mean }\end{array}$ \\
\hline \multirow{2}{*}{ Loyalty Mean } & public & 200 & 4.8599 & .90695 & .06413 \\
\cline { 2 - 6 } & private & 200 & 4.4693 & 1.04132 & .07363 \\
\hline
\end{tabular}

Levene's Test for Equality of Variances determines if the two conditions have about the same or different amounts of variability between scores. It is displayed in the table below:

\begin{tabular}{|c|c|c|c|c|c|c|c|c|c|c|}
\hline \multicolumn{11}{|c|}{ Independent Samples Test } \\
\hline & & \multicolumn{2}{|c|}{$\begin{array}{l}\text { Levene's Test } \\
\text { for Equality } \\
\text { of Variances }\end{array}$} & \multicolumn{7}{|c|}{ t-test for Equality of Means } \\
\hline & & \multirow[t]{2}{*}{$\mathrm{F}$} & \multirow[t]{2}{*}{ Sig. } & \multirow[t]{2}{*}{$\mathrm{t}$} & \multirow[t]{2}{*}{ df } & \multirow[t]{2}{*}{$\begin{array}{l}\text { Sig. } \\
(2- \\
\text { tailed })\end{array}$} & \multirow[t]{2}{*}{$\begin{array}{l}\text { Mean } \\
\text { Differ- } \\
\text { ence }\end{array}$} & \multirow{2}{*}{$\begin{array}{c}\text { Std. } \\
\text { Error } \\
\text { Differ- } \\
\text { ence }\end{array}$} & \multicolumn{2}{|c|}{$\begin{array}{l}95 \% \text { Confidence } \\
\text { Interval of the Dif- } \\
\text { ference }\end{array}$} \\
\hline & & & & & & & & & Lower & Upper \\
\hline \multirow{2}{*}{ 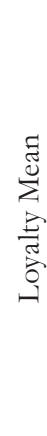 } & $\begin{array}{c}\text { Equal } \\
\text { vari- } \\
\text { ances } \\
\text { as- } \\
\text { sumed }\end{array}$ & 14.570 & .000 & 4.000 & 398 & .000 & .39057 & .09764 & .19861 & .58254 \\
\hline & $\begin{array}{c}\text { Equal } \\
\text { vari- } \\
\text { ances } \\
\text { not as- } \\
\text { sumed }\end{array}$ & & & 4.000 & 390.638 & .000 & .39057 & .09764 & .19860 & .58255 \\
\hline
\end{tabular}

\begin{tabular}{|c|c|c|c|c|c|c|c|c|c|}
\hline \multicolumn{10}{|c|}{ Model Summary } \\
\hline \multirow[b]{2}{*}{$\begin{array}{c}\text { Mod- } \\
\text { el }\end{array}$} & \multirow[b]{2}{*}{$\mathrm{R}$} & \multirow[b]{2}{*}{$\begin{array}{c}\mathrm{R} \\
\text { Square }\end{array}$} & \multirow[b]{2}{*}{$\begin{array}{c}\text { Adjust- } \\
\text { ed R } \\
\text { Square }\end{array}$} & \multirow{2}{*}{$\begin{array}{l}\text { Std. } \\
\text { Error of } \\
\text { the Esti- } \\
\text { mate }\end{array}$} & \multicolumn{5}{|c|}{ Change Statistics } \\
\hline & & & & & $\begin{array}{l}\text { R Square } \\
\text { Change }\end{array}$ & F Change & df1 & df2 & $\begin{array}{c}\text { Sig. F } \\
\text { Change }\end{array}$ \\
\hline 1 & $.996 a$ & .992 & .992 & .08842 & .992 & 7156.036 & 7 & 392 & .000 \\
\hline
\end{tabular}

a. Predictors: (Constant), Communication, Switching Cost, Customer Satisfaction , Commitment, Service Quality , Trust, Corporate Image 


\begin{tabular}{|c|c|c|c|c|c|c|}
\hline \multicolumn{2}{|c|}{ ANOVA } \\
\hline \multicolumn{2}{|c|}{ Model } & $\begin{array}{c}\text { Sum of } \\
\text { Squares }\end{array}$ & df & $\begin{array}{c}\text { Mean } \\
\text { Square }\end{array}$ & F. & Sig \\
\hline \multirow{3}{*}{1} & Regression & 391.662 & 7 & 55.952 & $7.156 \mathrm{E} 3$ & $.000 \mathrm{a}$ \\
\cline { 2 - 7 } & Residual & 3.065 & 392 & .008 & & \\
\cline { 2 - 8 } & Total & 394.727 & 399 & & & \\
\hline
\end{tabular}

a. Predictors: (Constant), Communication, Switching Cost , Customer Satisfaction , Commitment, Service Quality, Trust, Corporate Image

b. Dependent Variable: Customer Loyalty

\begin{tabular}{|c|c|c|c|c|c|c|c|c|}
\hline \multicolumn{9}{|c|}{ Coefficientsa } \\
\hline & \multirow{2}{*}{ Model } & \multicolumn{2}{|c|}{$\begin{array}{l}\text { Unstandardized } \\
\text { Coefficients }\end{array}$} & \multirow{2}{*}{$\begin{array}{c}\text { Stand- } \\
\text { ardized } \\
\text { Coeffi- } \\
\text { cients }\end{array}$} & \multirow{2}{*}{$\mathrm{t}$} & \multirow{2}{*}{ Sig. } & \multicolumn{2}{|c|}{$\begin{array}{c}\text { Collinearity Sta- } \\
\text { tistics }\end{array}$} \\
\hline & & B & $\begin{array}{l}\text { Std. Er- } \\
\text { ror }\end{array}$ & & & & $\begin{array}{l}\text { Toler- } \\
\text { ance }\end{array}$ & VIF \\
\hline \multirow{8}{*}{1} & (Constant) & .174 & .040 & & 4.336 & .000 & & \\
\hline & $\begin{array}{l}\text { Service } \\
\text { Quality }\end{array}$ & .356 & .011 & .310 & 32.749 & .000 & .222 & 4.511 \\
\hline & $\begin{array}{l}\text { Customer } \\
\text { Satisfaction }\end{array}$ & .010 & .005 & .013 & 1.794 & .074 & .392 & 2.549 \\
\hline & Trust & .166 & .007 & .235 & 24.469 & .000 & .215 & 4.655 \\
\hline & Commitment & .220 & .005 & .321 & 46.817 & .000 & .421 & 2.375 \\
\hline & $\begin{array}{l}\text { Corporate } \\
\text { Image }\end{array}$ & .110 & .006 & .191 & 17.927 & .000 & .174 & 5.760 \\
\hline & $\begin{array}{l}\text { Switching } \\
\text { Cost }\end{array}$ & .075 & .005 & .079 & 15.370 & .000 & .759 & 1.318 \\
\hline & $\begin{array}{l}\text { Communica- } \\
\text { tion }\end{array}$ & .037 & .004 & .083 & 9.096 & .000 & .238 & 4.208 \\
\hline
\end{tabular}

a. Dependent Variable: Customer Loyalty 


\begin{tabular}{|c|c|c|c|c|c|c|c|c|c|c|c|}
\hline \multicolumn{12}{|c|}{ Collinearity Diagnosticsa } \\
\hline \multirow[b]{2}{*}{$\begin{array}{l}\bar{v} \\
\frac{0}{2}\end{array}$} & \multirow[b]{2}{*}{ 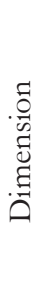 } & \multirow[b]{2}{*}{ 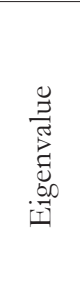 } & \multirow[b]{2}{*}{ 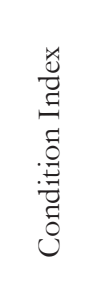 } & \multicolumn{8}{|c|}{ Variance Proportions } \\
\hline & & & & 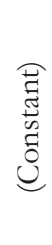 & 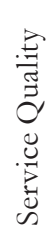 & 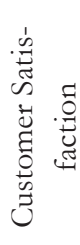 & $\underset{⿱ 乛}{\vec{D}}$ & 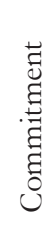 & 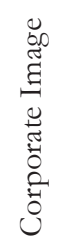 & 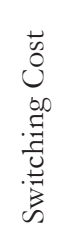 & 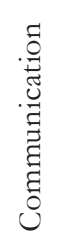 \\
\hline \multirow{8}{*}{1} & 1 & 7.610 & 1.000 & .00 & .00 & .00 & .00 & .00 & .00 & .00 & .00 \\
\hline & 2 & .212 & 5.998 & .01 & .00 & .00 & .00 & .00 & .01 & .04 & .11 \\
\hline & 3 & .079 & 9.796 & .00 & .00 & .03 & .00 & .33 & .00 & .05 & .16 \\
\hline & 4 & .046 & 12.917 & .00 & .00 & .27 & .10 & .17 & .08 & .01 & .00 \\
\hline & 5 & .020 & 19.340 & .05 & .00 & .00 & .48 & .24 & .10 & .01 & .64 \\
\hline & 6 & .017 & 21.353 & .05 & .01 & .31 & .11 & .16 & .52 & .25 & .05 \\
\hline & 7 & .011 & 25.977 & .38 & .06 & .39 & .03 & .07 & .18 & .63 & .04 \\
\hline & 8 & .005 & 39.969 & .51 & .93 & .00 & .27 & .02 & .11 & .00 & .00 \\
\hline
\end{tabular}

a. Dependent Variable: Customer Loyalty 